\title{
STRATEGI MANAGEMEN LABA DARI LEVERAGE: BUKTI EMPIRIS PERUSAHAAN KELUARGA DAN NON-KELUARGA
}

\author{
RUSTAM HANAFI \\ Universitas Islam Sultan Agung, Jl. Raya KM. 4 PO. Box 1054/SM Semarang, Indonesia \\ rustam@unissula.ac.id
}

\begin{abstract}
This study aims to examine whether leverage is related to earnings management in family and nonfamily firms. This study also examines the role of family control in the relationship between leverage and earnings management. The sample selection of this study used a purposive sampling method so that the total sample that met was 264 firms. This study uses multiple regression analysis to determine the relationship between leverage and earnings management and the involvement of family-controlled and non-family firms. The results of this study show that leverage and family ownership have a significant negative effect on earnings management. Furthermore, the effect of leverage on earnings management is stronger for family-controlled firms than controlled by nonfamilies. This result supports the view of entrechment, where family-controlled firms take over the wealth of minority shareholders for personal gain and hide by managing earnings, especially when the source of funding is through debt.
\end{abstract}

Keywords: Leverage, earnings management, family ownership, entrechment

Abstrak: Penelitian ini bertujuan untuk menguji apakah leverage berhubungan dengan manajemen laba pada perusahaan keluarga dan non-keluarga. Penelitian ini juga menguji peran pengendalian keluarga pada hubungan antara leverage dengan managemen laba. Seleksi sampel penelitian ini menggunakan metode purposive sampling sehingga total sampel yang memenuhi adalah sebanyak 264 perusahaan. Penelitian ini menggunakan analisis regresi berganda untuk menentukan hubungan antara leverage dengan manajemen laba dan keterlibatan perusahaan yang dikendalikan keluarga dan non-keluarga. Hasil penelitian ini menunjukkan bahwa leverage dan kepemilikan keluarga berpengaruh negatif signifikan pada manajemen laba. Selanjutnya, pengaruh leverage terhadap manajemen laba lebih kuat bagi perusahaan yang dikendalikan keluarga daripada dikendalikan nonkeluarga. Hasil ini mendukung pandangan entrechment, dimana perusahaan yang dikendalikan keluarga mengambil alih kekayaan pemegang saham minoritas untuk kepentingan pribadi dan menyembunyikan dengan melakukan manajemen laba khususnya ketika sumber pendanaannya melalui hutang.

Kata kunci: Leverage, manajemen laba, kepemilikan keluarga, entrechment

\section{PENDAHULUAN}

Perusahaan dalam mengembangkan usahanya membutuhkan sumber dana. Secara umum sumber dana perusahaan berasal dari hutang dan equitas (Brigham dan Houston 2011). Gabungan antara hutang dan ekuitas untuk mendanai kegiatan perusahaan dikenal dengan struktur modal (Azhagaiah dan Gavoury 2011). Kebijakan terhadap struktur modal 
merupakan pilihan antara risiko dan tingkat pengembalian (Prananda et al. 2019). Dalam beberapa literatur (Anderson et al. 2003, Boubakri \& Ghouma 2010, Lin et al. 2011) telah mengekplor dampak kepemilikan keluarga pada biaya agensi shareholder-debtholder dari hutang. Dalam studi ini, lebih fokus pada hubungan perilaku manajemen laba akibat kebijakan hutang yang dimiliki perusahaan dengan kepemilikan saham yang dikendalikan keluarga. Karena kepemilikan keluarga yang kuat memberikan insentif dan kapasitas yang lebih untuk monitoring dan mengambil alih (Demsetz \& Lehn 1985, Shleifer \& Vishny 1997, Burkart et al. 2003). Situasi ini akan membawa pengendalian keluarga berdampak positif atau negatif pada cost of debt perusahaan tergantung dominasi insentif entrenchment atau alignment (Ma et al., 2015). Oleh karena itu, studi terdahulu banyak menggunakan teori agensi sebagai kerangka teori dalam menjelaskan temuan mereka. Namun teori ini masih meberikan dua pandangan yang berbeda, yaitu padangan efek alignment dan entrenchment (Shahzad et al. 2017; Lassoued et al., 2018).

Pandangan alignment umumnya terjadi di negara maju, di mana perusahaan keluarga sulit mengambil alih kekayaan pemegang saham minoritas. Oleh karenanya, alignment pemegang saham dan manajer dalam perusahaan keluarga cendrung terlibat manajemen laba akrual yang lebih rendah dibandingkan dengan perusahaan non-keluarga (Cascino et al. 2010, Prencipe et al. 2011, Chen et al. 2014). Sebaliknya, pandangan entrenchment umumnya terjadi di negara yang belum maju perekonominya dengan tata kelola perusahaan yang belum baik. Oleh karenanya, memungkinkan dan memfasilitasi perusahaan keluarga untuk mengambil alih kekayaan pemegang saham minoritas melalui manajemen laba (Yang 2010, Ding et al. 2011). Hal ini sejalan dengan penelitian Shahzad et al., (2017) dengan seting penelitian di Pakistan. Mereka menemukan bahwa leverage berhubungan negatif dengan manajemen laba akrual dan berhubungan positif dengan manajemen laba riel. Dimana, dampak leverage terhadap manajemen laba akrual dan riel lebih kuat untuk perusahaan yang dikendalikan oleh keluarga daripada non-keluarga.

Indonesia yang dikategorikan sebagai negara berkembang, mempunyai struktur perusahaan yang banyak dikendalikan oleh keluarga, menarik untuk diteliti. Beberapa studi sebelumnya masih menunjukkan hasil yang berbeda-beda. Leverage mempunyai berpengaruh positif signifikan terhadap manajemen laba (Guna \& Herawaty 2010, Putri \& Titik 2014, Astuti et al. 2017, Hasty \& Herawaty 2017, Susanty 2019, Susanto, Pirzada, \& Adrianne 2019). Sementara studi lain menunjukkan bahwa leverage berpengaruh negatif terhadap manajemen laba (Dian 2013, Mahiswari \& Nugroho 2014, Gunarti 2015, Asitalia \& Trisnawati 2017, Dewi \& Wirawati 2019).

Adanya perbedaan hasil tersebut menarik untuk diteliti lebih lanjut karena kemungkinan ada keterlibatan variabel atau faktor lain meskipun ada dua pandangan alignment dan entrenchment. Namun dengan seting penelitian yang sama semestinya mendapatkan hasil atau pandangan yang sama. Berdasarkan kajian dan review di atas, seting penelitian di Indonesia patut diduga bahwa hasil sesuai dengan pandangan entrenchment karena Indonesia termasuk negara berkembang atau kategori negara belum maju. Meskipun tahun 2020 AS memasukkan Indonesia sebagai negara maju (Indris 2020) tetapi menurut Ramli (2020) Indonesia belum tepat disebut negara maju karena menurut bank dunia dikatakan negara maju bila pendapatan nasional bruto sudah mencapai 12.000 dolar AS perkapita. Sedang Indonesia masih 3.840 dolar AS perkapita.

Oleh karenanya, hasil penelitian ini juga bisa menangkap apakah Indonesia kategori negara maju atau belum dengan melihat apakah 
hasil penelitian ini sesuai dengan pandangan alignment atau entrenchment. Namun, penelitian ini tidak fokus apakah negara maju atau belum tetapi lebih fokus pada bagaimana peran perusahaan yang kepemilikannya dikendalikan keluarga dan non-keluarga terhadap hubungan antara leverage dengan manajemen laba.

\section{Leverage dan Manajemen Laba}

Teori agensi menganggap bahwa leverage memiliki peran penting dalam menyelaskan kepentingan manajer dengan pemegang saham. Menurut teori agensi Jensen dan Meckling (1976) dan teori arus kas bebas Jensen (1986), leverage memainkan peran yang disiplin dalam memantau aktivitas diskresi manajer dengan cara membatasi akses mereka ke arus kas perusahaan. Leverage dapat mengurangi biaya agensi yang disebabkan oleh konflik kepentingan dan asimetri informasi. Perilaku manajemen yang menikmati tunjangan berlebihan, membangun kerajaan keluarga, dan memfasilitasi kerabat mereka dengan menempatkan pada posisi kunci dapat dibatasi dengan mekanisme leverage (Jensen, 1986). Sejalan dengan studi Shahzad et al. (2017) menemukan bahwa leverage yang semakin tinggi akan membatasi perilaku managemen laba akrualnya semakin rendah. Meskipun leverage adalah cara untuk mengurangi konflik dan mengurangi biaya asimetri informasi antara pemegang saham dan manajer, bagaimanapun, akan menimbulkan masalah perbedaan kepentingan antara pemegang obligasi dengan pemegang saham dan pemegang obligasi dengan manajer (Lazzem \& Jilani, 2018).

Leverage dan manajemen laba sangat erat kaitannya. Leverage merupakan rasio untuk menghitung berapa besarkah kewajiban hutang yang harus dipenuhi oleh aktiva. Jika semakin besar suatu laverage perusahaan maka perusahaan dianggap kurang mampu membayar kewajiban dengan baik. Untuk menarik para investor supaya tetap menanamkan saham pada perusahaannya maka manajer akan berusaha menampakkan aktiva yang lebih tinggi dengan hutang yang lebih rendah. Investor umumnya mengharapkan keuntungan yang lebih tinggi dengan resiko yang lebih rendah. Namun kreditor tidak menginginkan hal ini terjadi. Oleh karenanya, kreditor akan berusaha mempersempit manajer untuk melakukan tindakan managemen laba. Pada negara maju dengan sistem hukum yang kuat kreditor bisa membatasi tindakan manajemen laba (Cascino et al. 2010, Prencipe et al. 2011, Chen et al. 2014). Sebaliknya, pada negara yang belum maju ekonominya dengan sistem hukum yang lemah maka kreditur lemah untuk membatasi tindakan managemen laba (Yang 2010, Ding et al. 2011, Susanto, Pradipta, \& Cecilia 2019).

Beberapa studi yang pernah dilakukan di Indonesia, terkait hubungan antara leverage dan manajemen laba, menunjukkan hasil yang berbeda-beda. Leverage berpengaruh negatif signifikan terhadap manajemen laba (Dian 2013, Mahiswari \& Nugroho 2014, Gunarti 2015, Asitalia \& Trisnawati 2017, Dewi \& Wirawati 2019). Sebaliknya, leverage mempunyai pengaruh positif signifikan terhadap manajemen laba (Guna \& Herawaty 2010, Putri \& Titik 2014, Astuti et al. 2017, Hasty \& Herawaty 2017, Susanty 2019, Susanto, et al. 2019). Berdasarkan kajian literatur tersebut, maka hipotesis yang diajukan adalah:

H1: Leverage berpengaruh negatif (positif) signifikan terhadap manajemen laba.

\section{Leverage, Kepemilikan keluarga dan Manajemen laba}

Beberapa literatur sebelumnya telah menguji hubungan antara kepemilikan keluarga dan non-keluarga dengan manajemen laba. Namun, temuan tentang hubungan antara 
kepemilkan keluarga dengan manajemen laba juga masih berbeda-beda. Beberapa studi menemukan bahwa perusahaan yang kepemilikannya dikendalikan oleh keluarga berhubungan negatif dengan manajemen laba (Prencipe et al. 2011, Jara \& Lopez 2011, Chen et al. 2015; Dwiyanti dan Astriena, 2018). Mereka menyatakan bahwa bisnis keluarga membatasi perilaku oportunistik manajemen dan karenanya menghasilkan manajemen laba yang lebih rendah (efek alignment). Sebaliknya, studi yang lain menemukan bahwa kepemilikannya dikendalikan oleh keluarga berhubungan positif dengan manajemen laba (Yang 2010, Ding et al. 2011, Chi et al. 2015, Chen et al. 2014). Mereka menyatakan bahwa perusahaan yang kepemilikannya dikendalikan keluarga memberikan peluang bagi mereka untuk terlibat melakukan manajemen laba (efek entrenchment).

Martin et al. (2015) menyatakan bahwa ada hubungan kepemilikan keluarga dengan manajemen laba. Jika ada hubungan antara anggota keluarga dan manajer dalam mengelola perusahaan maka mereka akan mementingkan keuntungan jangka panjang dan anggota keluarga sebagai pemegang saham mayoritas dengan mengorbankan pemegang saham minoritas (Adiguzel 2013). Studi ini sejalan dengan Shahzad et al. (2017) yang menemukan bahwa ada pengaruh leverage terhadap manajemen laba dengan perusahaan yang dikendalikan keluarga lebih kuat dibanding nonkeluarga. Dalam seting Indonesia, Suprianto et al. (2019) menemukan bahwa pengendalian keluarga oleh generasi pertama berdampak negatif terhadap manajemen laba. Hal yang sama disampaikan oleh Dwiyanti dan Astriena (2018) bahwa kepemilikan keluarga berpengaruh negative terhadap manajemen laba. Oleh karenanya, hipotesis yang diajukan adalah:

H2a: Kepemilikan keluarga berpengaruh negatif (positif) terhadap manajemen laba.
$\mathrm{H} 2 \mathrm{~b}$ : Leverage yang dikendalikan oleh perusahaan keluarga lebih terlibat dalam manajemen laba dibanding leverage yang dikendalikan nonkeluarga.

\section{METODA}

Data yang digunakan dalam studi ini merupakan data sekunder. Data diambil dari laporan keuangan perusahaan manufaktur yang terdaftar di Bursa Efek Indonesia (BEI) pada tahun 2016-2018. Teknik pengambilan sampel menggunakan purposive sampling, sehingga total sampel yang diperoleh sebanyak 264 sampel.

Pengukuran manajemen laba (Earnings Management) diproksi dengan discretionary accrual sesuai dengan Modified Jones Models Dechow (1996) sebagai berikut:

Model Jones,

$$
\frac{T A C C_{i t}}{T A_{i t-1}}=\alpha_{1}\left(\frac{1}{T A_{i t-1}}\right)+\alpha_{2}\left(\frac{\Delta \operatorname{Re} v_{i t}}{T A_{i t-1}}\right)+\alpha_{3}\left(\frac{P P E_{i t}}{T A_{i t-1}}\right)+\varepsilon_{i t}
$$

Model Jones yang dimodifikasi,

$$
\begin{aligned}
& \frac{T A C C_{i t}}{T A_{i t-1}}=\alpha_{1}\left(\frac{1}{T A_{i t-1}}\right)+\alpha_{2}\left(\frac{\Delta \operatorname{Rev}_{i t}-\Delta \operatorname{Re} c_{i t}}{T A_{i t-1}}\right)+\alpha_{3}\left(\frac{P P E_{i t}}{T A_{i t-1}}\right)+\varepsilon_{i t} \\
& D C_{\text {it }}=T A C C_{i t}-N D A C C_{i t}
\end{aligned}
$$

Dimana,

DACC discretionary accrual

NDACC non-discretionary accrual

TACC total accruals, selisih antara laba bersih dan arus kas operasi

TA total Asset

$\triangle \operatorname{Rev}$ perubahan revenue

$\Delta \mathrm{rec} \quad$ perubahan receivable 
PPE gross property, plant and equipment.

i,t perusahaan dan tahun

Leverage merupakan ratio solvabilitas yaitu kemampuan perusahaan untuk memenuhi kewajiban keuangannya. Leverage dihitung dengan menggunakan persamaan sebagai berikut:

$$
\text { Leverage }=\text { Debt } / \text { Assets }
$$

Dalam studi ini, perusahaan yang dikategorikan perusahaan keluarga apabila ada keterkaitan oleh keluarga atau anggota keluarga dengan dewan direksi. Penelitian ini menggunakan dummy variable, dummy " 1 " merupakan perusahaan yang dimiliki dan dikendalikan oleh keluarga dan "0" jika dimiliki dan dikendalikan oleh non-keluarga.

Dalam penelitian menggunakan empat variabel kontrol yaitu ukuran perusahaan, pertumbuhan, ROA dan kualitas audit. Ukuran perusahaan menggunakan pengukuran logaritma natural dari total aset perusahaan, pertumbuhan diukur dengan menggunakan rasio market to book ratio, ROA dihitung dengan total laba bersih dibagi dengan total aset serta kualitas audit dengan kode 1 jika BIG4 dan kode 0 jika tidak.

Model regresi dikembangkan bertujuan untuk menguji hipotesis yang sudah dirumuskan dalam penelitian ini adalah :

$$
\begin{aligned}
E M= & \alpha+\beta_{1} L E V+\beta_{2} F C F+\beta_{3} F C F^{*} L E V+\beta_{4} F S+\beta_{5} \\
& G 0+\beta_{6} R O A+\beta_{7} A Q+e
\end{aligned}
$$

Dimana,

$$
\begin{array}{ll}
\text { EM } & =\text { Earning Management } \\
\beta & =\text { koefesien regresi } \\
\text { Lev } & =\text { Leverage } \\
\text { FCF } & =\text { Family Controlled Firms } \\
\text { FS } & =\text { Firm Size } \\
G O & =\text { Growth Opportunity } \\
R O A & =\text { Return on Assets } \\
A Q & =\text { Audit Quality } \\
e & =\text { Error }
\end{array}
$$

\section{HASIL DAN DISKUSI}

Statistik deskriptif pada tabel 1 menjadi 3 bagian: Sampel penuh ( $\mathrm{N}=264), \mathrm{FCF}(\mathrm{N}=63)$ dan NFCF $(N=201)$. Sampel penuh 264 perusahaan, termasuk 63 perusahaan yang dikendalikan keluarga dan 201 perusahaan yang tidak dikendalikan keluarga. Variabel utama pada sampel penuh, manajemen laba mepunyai rata-rata $(0,003)$, minimum $(-1,355)$, maksimum $(0,331)$ dan standar deviasi $(0,137)$. Hal ini menunjukkan bahwa data manajemen laba cenderung menyebar. Sedangkan Leverage mempunyai rata-rata $(0,417)$, minimum $(0,080)$, maksimum $(0,830)$ dan standar deviasi $(0,182)$. Hal ini menunjukkan bahwa data leverage cenderung merata.

Tabel 1 Hasi Uji Statistik Deskriptif

\begin{tabular}{lllll}
\hline Variabel & Mean & Min & Max & SD \\
\hline Sampel penuh (N=264) & & & & \\
Earning Management (EM) & 0.003 & -1.355 & 0.331 & 0.137 \\
Leverage (LEV) & 0.417 & 0.08 & 0.83 & 0.184 \\
Family Control Firms (FCF) & 0.239 & 0.00 & 1.00 & 0.427 \\
Firm Size (FS) & 14.93 & 11.82 & 19.66 & 1.549 \\
Growth Opportunity (GO) & 45.22 & 0.00 & 1054.3 & 102.9
\end{tabular}




\begin{tabular}{lllll} 
Return on Assets (ROA) & 7.112 & 0.00 & 52.67 & 7.502 \\
Audit Quality (AQ) & 0.477 & 0.02 & 1.00 & 0.500 \\
\hline Sampel FCF (N=63) & & & & \\
Earning Management (EM) & 0.024 & -0.266 & 0.331 & 0.141 \\
Leverage (LEV) & 0.357 & 0.10 & 0.79 & 0.159 \\
Firm Size (FS) & 14.81 & 11.98 & 19.66 & 1.949 \\
Growth Opportunity (GO) & 28.98 & 0.00 & 313.52 & 50.11 \\
Return on Assets (ROA) & 5.625 & 0.11 & 16.74 & 3.669 \\
Audit Quality (AQ) & 0.429 & 0.00 & 1.00 & 0.498 \\
\hline Sampel NFCF (N=201) & & & & \\
Earning Management (EM) & -0.004 & -1.355 & 0.228 & 0.136 \\
Leverage (LEV) & 0.435 & 0.08 & 0.83 & 0.187 \\
Firm Size (FS) & 14.97 & 11.82 & 18.68 & 1.404 \\
Growth Opportunity (GO) & 50.31 & 0.01 & 1054.3 & 114.2 \\
Return on Assets (ROA) & 7.585 & 0.02 & 52.67 & 8.302 \\
Audit Quality (AQ) & 0.493 & 0.00 & 1.00 & 0.501 \\
\hline
\end{tabular}

Analisis perbedaan rata-rata dilakukan untuk mengetahui perbedaan variabel utama, manajemen dan Leverage, yang dikendalikan keluarga dan non-keluarga. Berdasarkan tabel 1 menunjukkan bahwa rata-rata perusahaan yang dikendalikan keluarga memiliki manajemen laba lebih tinggi dibandingkan dengan perusahaan yang tidak dikendalikan oleh keluarga dengan nilai rata-rata 0,024 dan -0.004 . Namun, berdasarkan tabel 2 perbedaan manajemen laba pada perusahan yang dikendalikan keluarga dan non-keluarga tersebut tidak signifikan $(0,161>0,05)$. Hal ini dapat dinyatakan bahwa tindakan manajemen laba yang terjadi pada perusahaan yang dikendalikan oleh keluarga dan non-keluarga tidak berbeda secara signifikan. Selanjutnya, perusahaan yang dikendalikan oleh keluarga memiliki rata-rata pembiayaan utang lebih sedikit dibandingkan dengan perusahaan non-keluarga yaitu $35,7 \%$ dan $43,5 \%$. Berdasarkan tabel 2, pembiayaan hutang tersebut berbeda signifikan $(0.003<0.005)$. Hal ini dapat dinyatakan bahwa perusahaan non-keluarga memiliki sumber pembiayaan hutang lebih besar dibanding perusahaan yang dikendalikan oleh keluarga.

Tabel 2 Uji Beda Mean

\begin{tabular}{llll}
\hline Variabel & FCF & NFCF & Different \\
\hline Earning Management (EM) & 0.024 & -0.004 & 0.161 \\
Leverage (LEV) & 0.357 & 0.435 & 0.003 \\
Firm Size (FS) & 14.80 & 14.97 & 0.465 \\
Growth Opportunity (GO) & 28.97 & 50.31 & 0.151 \\
Return on Assets (ROA) & 5.625 & 7.585 & 0.070 \\
Audit Quality (AQ) & 0.429 & 0.493 & 0.377 \\
\hline
\end{tabular}


Estimasi persamaan regresi linier berganda (5) menggunakan metode Ordinary Least Square (OLS) untuk menguji Hipotesis 1 dan 2. Sebelum diuji dengan menggunakan model regresi linier barganda terlebih dahulu dilakukan uji asumsi klasik. Hasil uji asumsi klasik dari studi ini menunjukkan bahwa semua variabel terdistribusi normal, tidak mengandung multikolieritas, bebas autokorelasi dan tidak terjadi heteroskedastisitas (data terlampir). Tabel 3 menunjukkan estimasi persamaan (5) dengan memperhitungkan pengaruh variabel kontrol. Berdasarkan tabel tersebut menunjukkan bahwa leverage (LEV) berpengaruh negatif signifikan pada managemen laba (EM) $(0.005<0.05)$, dengan demikian $\mathrm{H} 1$ diterima. Sehingga dapat dinyatakan bahwa semakin tinggi leverage maka semakin rendah manajemen laba.
Selanjutnya, kepemilikan keluarga juga berpengaruh negatif signifikan terhadap manajemen laba $(0.035<0.05)$, sehingga $\mathrm{H} 2 \mathrm{a}$ diterima. Sehingga dapat dinyatakan bahwa semakin tinggi kepemilikan atau keterlibatan keluarga maka manajemen laba semakin rendah. Kepemilikan keluarga memoderasi hubungan antara leverage dengan managemen laba $(0.004<0.05)$, dengan demikian $\mathrm{H} 2 \mathrm{~b}$ diterima. Sehingga dapat dinyatakan bahwa Leverage yang dikendalikan oleh perusahaan keluarga lebih terlibat manajemen laba dibanding leverage yang dikendalikan nonkeluarga. Sementara untuk variabel kontrol yang signifikan Growth Opportunity pada level 10\% $(0.055<0.10)$. Sehingga dapat dinyatakan bahwa semakin tinggi peluang pertumbuhan maka semakin tinggi adanya tindakan manajemen laba.

Tabel 3 Hasil Regesi OLS pada Earning Management

\begin{tabular}{lll}
\hline Variabel Inependen & Koef. & Sig. \\
\cline { 2 - 3 } Leverage (LEV) & -0.146 & 0.005 \\
Family Control Firms (FCF) & -0.104 & 0.035 \\
FCF*LEV & 0.346 & 0.004 \\
Variabel Kontrol & & \\
Firm Size (FS) & 0.008 & 0.189 \\
Growth Opportunity (GO) & 0.0001 & 0.055 \\
Return on Assets (ROA) & -0.001 & 0.248 \\
Audit Quality (AQ) & 0.019 & \\
\hline R-squared & & 0.367 \\
Adjusted R-squared & & 0.091 \\
F-statistic & & 3.653 \\
Prob(F-statistic) & & 0.001 \\
\hline
\end{tabular}

Berdasarkan alat analisis diatas dapat dinyatakan sebagai berikut: pertama, ketika semakin tinggi tingkat utang maka semakin rendah terjadinya manajemen laba. Semakin banyak hutang yang dimiliki perusahaan maka debtholder semakin interest terhadap klaim piutangnya. Untuk menjaga kelancaran klaim tersebut, debetholder selalu berusaha meningkatkan pengawasan dan tekanan terhadap manejer sehingga mempersempit opportunity manajer untuk melakukan tindakan managemen laba yang merugikan klaim 
mereka. Studi ini sejalan dengan temuan (Dian, 2013; Mahiswari \& Nugroho, 2014; Gunarti, 2015; Shahzad et al., 2017; Asitalia \& Trisnawati, 2017; Dewi \& Wirawati, 2019) bahwa leverage berhubungan negatif dengan manajemen laba Akrual.

Kedua, semakin tinggi kepemilikan keluarga maka semakin rendah manajemen dalam melakukan tindakan manajemen laba. Artinya, keterlibatan kepemilikan keluarga akan memberi insetif untuk lebih menekan manajemen sehingga manajemen laba semakin rendah. Hal ini sejalan dengan penelitian (Tong 2007, Jiraporn dan Dadalt 2009, Prencipe et al. 2011, Chen et al. 2014, Dwiyanti dan Astriena 2018).

Ketiga, Ketika leverage diinteraksi dengan kepemilikan keluarga menunjukkan adanya peningkatan manajemen laba. Artinya bahwa ketika debtholder (pemberi / pemegang hutang) mempunyai pengawasan yang ketat terhadap manajemen atas klaim hutangnya maka kepentingan kepemilikan keluarga (shareholder-family) terganggu sehingga mereka melibatkan manajemen untuk melakukan tindakan manajemen laba. Timbul permasalahan perbedaan kepentingan antara pemegang hutang dengan pemegang saham dan pemegang hutang dengan manajer (Lazzem \& Jilani 2018). Hasil ini sesuai dengan (Shahzad et al. 2017) bahwa pengaruh leverage terhadap manajemen laba akrual lebih kuat untuk perusahaan yang dikendalikan keluarga daripada dikendalikan non-keluarga.

Hasil ini mendukung pandangan entrenchment dari teori agensi, yang menyatakan bahwa mekanisme tatakelola ekternal yang lemah memungkinkan dan memfasilitasi perusahaan keluarga mengambil alih kekayaan pemegang saham minoritas untuk kepentingan pribadi dan menyembunyikan dengan melakukan manajemen laba (Yang 2010, Ding et al. 2011) khususnya ketika sumber pendanaannya melalui hutang (Shahzad et al. 2017).

\section{PENUTUP}

Studi ini membuktikan bahwa variabel utama yang meliputi leverage dan kepemilikan keluarga berpengaruh negatif signifikan terhadap managemen laba. Namun ketika pengawasan debtholder dianggap menggnggu kepentingan kepemilikan keluarga (shareholdelfamily) maka kepemilikan keluarga bersama manajemen lebih terlibat dalam tindakan manajemen laba dibanding non-keluarga.

Penelitian ini memiliki keterbatasan jumlah data yang relatif kecil. Oleh karenanya, penelitian yang serupa diharapkan memperbanyak jumlah data sampel dengan cara menambah jenis industri. Selanjutnya, penelitian yang akan datang diharapkan memasukkan faktor lain yaitu kepemilikan terkonsentrasi atau blokholder yang mempunyai kendali selain shareholder-family. Sehingga secara teori maupun empiris memberikan keyakinan bahwa penelitian dengan seting yang sama masih sesuai dengan pandangan entrenchment yaitu ketika shareholder terkonsentrasi atau terblok maka manajemen laba cendrung meningkat.

\section{REFERENCES:}

Adiguzel. 2013. Corporate Gonernance, Family Ownership and Earning Manajemen: Emerging Market Evidence. Accounting and Finance Research, 2(4), 17-33

Anderson, R., Mansi, S., Reeb, D. 2003. Founding family ownership and the agency cost of debt. Journal of Financial Economics, 68, 263-285. 
Asitalia, F. dan Trisnawati, I. 2017. Pengaruh Good Corporate Governance Dan Leverage Terhadap Manajemen Laba. Jurnal Bisnis dan Akuntansi, 19(1a), 109-119

Astuti, A.Y., Nuraina, E., Wijaya, A.L. 2017. Pengaruh Ukuran Perusahaan Dan Leverage Terhadap Manajemen Laba. Fipa Forum Ilmiah Pendidikan Akuntansi, 5(1), 501-512

Azhagaiah, R., \& Gavoury, C. 2011. The Impact of Capital Structure on Profitability with Special Reference to IT Industry in India vs. Domestic Products. Managing Global Transitions, 9(4), 371-392.

Boubakri, N., \& Ghouma, H. 2010. Control/ownership structure, creditor rights protection, and the cost of debt financing: International evidence. Journal of Banking and Finance, 34, 2481-2499.

Burkart, M., Panunzi, F., Shleifer, A. 2003. Family firms. The Journal of Finance, 58, 2167-2202.

Brigham, E. F., \& Houston, J. F. 2011. Dasar-Dasar Manajemen Keuangan (11th ed.). Jakarta: Salemba Empat.

Cascino, S., Pugliese, A., Mussolino, D., Sansone, C. 2010. The Influence of Family Ownership on the Quality of Accounting Information. Family Business Review 23 (3), 1-36

Chen, T.Y., Gu, Z., Kubota, K., Takehara, H. 2015. Accrual-Based and Real Aktivies Based Earnings Management Behavior of Family Firms in Japan. The Japanese Accounting Review, 5, 21-47

Chen, S., Chen, X., Cheng, Q. 2014. Conservatism and Equity Ownership of the Founding Family. European Accounting Review, 23(3), 1-45

Chi, C.W., Hung, K., Lieu, P.T. 2015. Family firms and Earnings Management in Taiwan: Influence of corporate governance", International Review of Economics \& Finance, 36.(C), 88-98

Dechow, P.M., Sloan R.G., Sweeney, A.P. 1996. Causes and Consequences of Earnings Manipulation: An Analysis of Firms Subject to Enforcement Actions by the SEC. Contemporary Accounting Research, 13 (1), 1-36

Demsetz, H., \& Lehn, K. 1985. The structure of corporate ownership. Journal of Political Economy, 93, 1155-1177.

Dewi, P.E.P dan Wirawati, N.G.P. 2019. Pengaruh Leverage Terhadap Manajemen Laba Dengan Corporate Governance Sebagai Variabel Pemoderasi. E-Jurnal Akuntansi Universitas Udayana, 27(1), 505-533

Dian, A. 2013. Pengaruh Faktor Good Corporate Governance, Free Cash Flow, dan Leverage Terhadap Manajemen Laba. Jurnal Akuntansi dan Keuangan, 15(1), 27-42

Ding, S., Qu, B., Zhuang, Z. 2011. Accounting Properties of Chinese Family Firms. Journal of Accounting, Auditing and Finance, 26(4), 623-640

Dwiyanti, K. dan Astriena, M. 2018. Pengaruh Kepemilikan keluarga dan Karakteristik Komite Audit Terhadap Manajemen Laba. Jurnal Riset Akuntansi dan Bisnis Airlangga, 3(2), 447- 469

Guna, W. dan Herawaty, A. 2010. Pengaruh Mekanisme Corporate Governance, Independensi Auditor, Kualitas Audit dan Faktor Lainnya Terhadap Manajemen Laba. Jurnal Bisnis dan Akuntansi, 12(1), 53 - 68

Gunarti, Y. 2015. Pengaruh Struktur Kepemilikan, Return On Asset Dan Leverage Terhadap Manajemen Laba. Jurnal Akuntansi dan Sistem Teknologi, 11(1), 9-16

Hasty, A. dan Herawaty, V. 2017. Pengaruh Truktur Kepemilikan, Leverage, Profitabilitas dan kebijakan Dividen Terhadap Manajemen Laba dengan Kualitas Audit sebagai Variabel Moderasi. Media Riset Akuntansi, Auditing dan Informasi, 17(1), 1-16

Idris, M. 2020 Indonesia Masuk Negara Maju atau Berkembang? Ini Penjelasan WTO. Kompas.com, https: //money.kompas.com/read/2020/02/22/115252426/indonesia-masuk-negara-maju-atau-berkembang-inipenjelasan-wto?page=all.

Jara, M. \& Lopez, F.j. 2011. Earnings Management and Contests for Control: An Analysis of European Family Firms. Journal of CENTRUM Cathedra, 4(1), 100-102

Jensen, M. \& Meckling, W. 1976. The Theory of The Firm: Managerial behavior, Agency Costs and Ownership Structure. Journal of Financial Economic, 3 (4), 305-360

Jensen, M. C. 1986. Agency cost of free cash flow, corporate finance, and takeovers. Corporate Finance, and Takeovers. The American Economic Review, 76(2), 323-329.

Jiraporn, P., \& DaDalt, P. J. 2009. Does founding family control affect earnings management? Applied Economics Letters, 16(2), 113-119.

Lazzem, S. \& Jilani, F. 2018. The impact of leverage on accrual-based earnings management: The case of listed French firms. Journal of Research in International Business and Finance, 44, 350-358 
Lassoued, N., Ben Rejeb Attia, M., Sassi, H. 2018. Earnings management in islamic and conventional banks: Does ownership structure matter? Evidence from the MENA region. Journal of International Accounting, Auditing and Taxation, 30, 85-105.

Lin, C., Ma, Y., Malatesta, P., Xuan, Y. 2011. Ownership structure and the cost of corporate borrowing. Journal of Financial Economics, 100, 1-23.

Mahiswari, R. dan Nugroho, P.I. 2014. Pengaruh Mekanisme Corporate Governance, Ukuran Perusahaan Dan Leverage Terhadap Manajemen Laba dan Kinerja Keuangan. Jurnal ekonomi dan Bisnis, 17(1), 1-20

Martin, G., Mejia, L., Campbell, J. 2015. Family Control, Socioemotional Weath and Earnings Management in Publicly Traded Firm. Journal of Bisiness Ethic, 1-31

Ma, L., Ma, S., Tian, G. 2015. Corporate Opacity and Cost of Debt for Family Firms. European Accounting Review, $11,1-34$

Prananda, C., Utama, U., Rinaningsih, Gunawan, V. P. 2019. Faktor Penentu Struktur Modal Pada Perusahaan Keluarga Dan Non-keluarga Di Indonesia. Jurnal Bisnis dan Akuntansi, 21(2), 179-194

Prencipe, A. \& Bar-Yosef, S. 2011. Corporate governance and earnings management in family-owned companies. Journal of Accounting, Auditing and Finance, 26(2), 199-227

Putri, M. dan Titik, F. 2014. Pengaruh Kepemilikan Manajerial, Leverage dan Ukuran Perusahaan Terhadap Manajemen Laba pada Perusahaan Food and Beverage. E-Proceeding of Management, 1, 1-17

Ramli, R., R. 2020. Indonesia Belum Cocok Jadi Negara Maju. Kompas.com, https://money.kompas.com /read/2020/02/27/191913626/indonesia-belum-cocok-jadi-negara-maju-ini alasannya.

Shahzad, F., Rauf, S., Rehman, I., Saeed, A., Barghouthi, S. 2017. Earning Management Strategies of Laveraged Family and non-Family Controlled Firms: An Empirical Evidence. Journal of Business and Society, 18, 503-518.

Shleifer, A., \& Vishny, R. W. 1997. A survey of corporate governance. The Journal of Finance, 52, 737-783.

Suprianto, E., Rahmawati, Setiawan, D. 2019. Controlling generation of family firms and earnings management in Indonesia: The role of accounting experts of audit committees. Journal of International Studies, 12(3), 265276

Susanto, Y.K., Pradipta, A., \& Cecilia, E. 2019. Earnings Management: Esop and Corporate Governance. Academy of Accounting and Financial Studies Journal, 23(Special Issue 1), 1-13.

Susanto Y.K., Pirzada K., \& Adrianne S., 2019, Is tax aggressiveness an indicator of earnings management?, Polish Journal of Management Studies, 20(2), 516-527.

Susanty, F.M. 2019. Tate Kelola Perusahaan, Aliran Kas Bebas dan Manajemen Laba. Jurnal Bisnis dan Akuntansi 21(2), 141-154

Tong, Y. H. (2007). Financial Reporting Practices of Family Firms. Advances in Accounting, 23, 231-261.

Yang, M.L. 2010. The Impact of Controlling Families and Family CEOs on Earnings Management. Family Business Review, 23(3), 266-279 